\title{
Identification of differentially expressed inflammatory factors in Wilms' tumors and their association with patient outcomes
}

\author{
FEI GUO ${ }^{1}$, JUNJIE ZHANG ${ }^{1}$, LEI WANG $^{1}$, WEI ZHAO ${ }^{1}$, JIEKAI YU ${ }^{2}$, SHU ZHENG $^{2}$ and JIAXIANG WANG ${ }^{1}$ \\ ${ }^{1}$ Department of Pediatric Surgery, The First Affiliated Hospital, Zhengzhou University, Zhengzhou, Henan 450052; \\ ${ }^{2}$ Institute of Cancer, The Second Affiliated Hospital, College of Medicine, \\ Zhejiang University, Hangzhou, Zhejiang 310000, P.R. China
}

Received October 7, 2015; Accepted March 17, 2017

DOI: $10.3892 / \mathrm{ol} .2017 .6261$

\begin{abstract}
The present study aimed to identify differentially expressed inflammatory factors observed in Wilms' tumors (WT), and to investigate the association of these factors with clinical stage, pathological type, lymph node metastasis and vascular involvement of WT. Surface-enhanced laser desorption/ionization-time of flight mass spectrometry was performed to screen differentially expressed proteins among WT and normal tissue pairs. Upregulated proteins in WT were separated and purified by solid phase extraction and Tricine SDS-PAGE, respectively. Following in-gel digestion, the peptide mixture was subjected to liquid chromatography mass spectrometry to identify proteins on the basis of their amino acid sequences. Immunohistochemistry was used to confirm the expression of differentially expressed inflammatory proteins. Of the proteins that were upregulated in WT, two proteins with mass/charge $(\mathrm{m} / \mathrm{z})$ ratio of 12,138 and 13,462 were identified as macrophage migration inhibitory factor (MIF) and C-X-C motif ligand 7 (CXCL7) chemokine, respectively. The expression of these two proteins was increased in WT compared with adjacent normal tissues and normal renal tissues, and increased with increasing clinical stage. In addition, their expression was significantly increased in patients with unfavorable pathological type, lymph node metastasis and vascular involvement compared with the groups with favorable type, and without lymph node metastasis or vascular involvement $(\mathrm{P}<0.05)$. Increased pro-inflammatory MIF and CXCL7 expression in WT is closely associated with the clinical stage, pathological type, lymph node metastasis and vascular involvement, and may represent biomarkers for the clinical diagnosis of WT.
\end{abstract}

Correspondence to: Professor Jiaxiang Wang, Department of Pediatric Surgery, The First Affiliated Hospital, Zhengzhou University, 1 Jianshe Dong Road, Erqi, Zhengzhou, Henan 450052, P.R. China

E-mail: drwangjx@163.com

Key words: macrophage migration inhibitory factor, chemokine, proteomics, Wilms' tumor, biomarkers

\section{Introduction}

Wilms' tumor (WT) is a retroperitoneal solid tumor commonly identified in children and the most common type of renal malignancy in children (1). Early diagnosis of WT is dependent on clinical symptoms and physical and imaging examinations, with pathological examination being the gold standard in WT diagnosis. Although laboratory examination cannot offer specific biomarkers for early diagnosis in WT, certain serum and urine indicators, including $\alpha$-fetoprotein, and catecholamine metabolites can effectively be used for differential diagnosis between hepatoblastoma and neuroblastoma. Complete resection and chemotherapy are currently the major therapeutic strategies for patients with WT. In addition, kidney transplantation is an effective alternative for the treatment of WT.

The development of mass spectrometry (MS) provides a novel platform for the investigation of diseases. Our group has employed proteomics to screen serum biomarkers in patients with breast cancer, thyroid cancer and WT, which may be useful for the early diagnosis of malignancies (2-4). In previous years, an increasing number of studies have confirmed that inflammatory cytokines are closely associated with oncogenesis, particularly to the growth, invasion, metastasis and immune escape of different types of cancer (5-8). However, the role of inflammatory cytokines in WT remains unclear. In the present study, proteomics was employed to identify differentially expressed inflammatory cytokines in WT and the results were confirmed using immunohistochemistry. Subsequently, associations between the altered expression of these cytokines with clinical stage, pathological type and other characteristics of WT were investigated, which may provide novel therapeutic targets for WT.

\section{Materials and methods}

Patients. A total of 40 children (mean age, $2.5 \pm 1.5$ years; median, 2.5 years; range, 0.3-5.2 years), including 23 males and 17 females, with WT were recruited between January 2010 and December 2014. Adjacent normal tissues $(1 \mathrm{~cm}$ away from the tumor) were collected from 35 patients, of whom there were 20 males and 15 females with a mean age of $2.2 \pm 1.3$ years (median, 2.1 years; range, $0.3-4.5$ years). Normal 
kidney tissues ( $5 \mathrm{~cm}$ away from the tumor) were collected from an additional 25 patients, of whom there were 14 males and 11 females with a mean age of $2.2 \pm 1.1$ years (median, 2.4 years; range, $0.5-4.2$ years). No patient received chemotherapy or radiotherapy prior to enrollment into the study, and pathological diagnosis of WT was confirmed by more than two pathologists.

Clinical stage and pathological type were determined according to the criteria described by the National Wilms' Tumor Study Group (1). Stage I WT was identified in 6 patients, stage II WT in 12, stage II WT in 13 and stage IV WT in 9. Favorable histology, as indicated by tissue primarily consisting of embryonal, epithelial and stromal cells, was noted in 33 patients, and unfavorable histology in 7 patients. In addition, the absence of lymph node metastasis was noted in 23 patients while 17 exhibited lymph node metastasis. Of the 40 patients, vascular involvement was identified in 9 . Fresh tissues $(20 \mathrm{mg})$ were lysed in $200 \mu \mathrm{l}$ lysis buffer $(50 \mathrm{mM}$ Tris, $150 \mathrm{mM} \mathrm{NaCl}, 1 \%$ sodium deoxycholate, $0.1 \%$ SDS, $1 \%$ NP-40, $1 \mathrm{mM}$ phenylmethane sulfonyl fluoride), followed by centrifugation at $10,000 \mathrm{xg}$ for $20 \mathrm{~min}$ at $4^{\circ} \mathrm{C}$. The supernatant was harvested and stored at $-80^{\circ} \mathrm{C}$. The present study was approved by the Ethics Committee of Zhengzhou University, and written informed consent was obtained from the patients parents prior to entry into the study.

Reagents and instruments. Surface-enhanced laser desorption/ionization-time of flight mass spectrometry (SELDI-TOF-MS), weak cation exchange (WCX)-2 SELDI protein chip and Bioprocessor equipment were purchased from Ciphergen Biosystems, Inc., (Fremont, CA, USA). Reagents used for SELDI-TOF-MS were obtained from Sigma-Aldrich; Merck KGaA (Darmstadt, Germany). The Tangential flow ultrafilter (Vivaflow 50) was purchased from Sartorius AG (Göttingen, Germany). The solid phase extraction (SPE) column was purchased from Sigma-Aldrich; Merck KGaA. A vacuum centrifugal concentrator and the protein markers (cat. no. 26628) were purchased from Thermo Fisher Scientific, Inc. (Waltham, MA, USA). The trypsin detection kit was obtained from Promega Corporation (Madison, WI, USA), and the matrix-assisted laser desorption/ionization-TOF-MS was from Bruker AXS GmbH (Karlsruhe, Germany). A rabbit polyclonal antibody [human macrophage migration inhibitory factor (MIF; cat. no. ab65869) and C-X-C motif ligand 7 chemokine (CXCL7; cat. no. ab169946)] and a goat anti-rabbit horseradish peroxidase-conjugated secondary antibody (cat. no. ab205718) were purchased from Abcam (Cambridge, UK).

Screening of inflammatory markers. Following lysis, samples were centrifuged at $4^{\circ} \mathrm{C}$ for $10 \mathrm{~min}$ at $10,000 \mathrm{xg}$, and the supernatant was collected and added into 96-well plates ( $5 \mu \mathrm{l} /$ well), followed by addition of U9 buffer \{9M urea, 2\% 3-[(3-cholamidopropyl) dimethylammonio]-1-propanesulfonate, $50 \mathrm{mM}$ Tris- $\mathrm{HCl}, 1 \%$ dithiotheritol (DTT), $\mathrm{pH} 9.0 ; 10 \mu \mathrm{l} / \mathrm{well}\}$. The plates were incubated at $4{ }^{\circ} \mathrm{C}$ with a constant agitation for $30 \mathrm{~min}$, and $185 \mu \mathrm{l} \mathrm{NaAc}(0.1 \mathrm{M}$ sodium acetate, $\mathrm{pH} 4.0)$ was subsequently added and vortexed for $5 \mathrm{~min}$. The WCX-2 SELDI protein chip was fixed in the Bioprocessor, and $\mathrm{NaAc}$ was added to each well $(200 \mu \mathrm{l} /$ well $)$ and vortexed at room temperature for $5 \mathrm{~min}$ in the rotating platform, repeat once.
The samples were added to the protein chip (100 $\mu \mathrm{l} /$ well) and vortexed at $4^{\circ} \mathrm{C}$ for $60 \mathrm{~min}$. The chip was dried, and $\mathrm{NaAc}$ was added (200 $\mu \mathrm{l} /$ well) and vortexed for $5 \mathrm{~min}$. This was repeated three times. Following two washes with $200 \mu \mathrm{l}$ deionized water to each well, $1 \mu 1$ of saturated SPA solution [SPA, $50 \%$ acetonitrile (ACN), $0.5 \%$ trifluoroacetic acid (TFA)] was added to each well, and the chip was air-dried. Finally, the chip was placed in the SELDI-TOF-MS machine for the detection of the protein peaks.

Identification of inflammatory cytokines. For sample processing, $1 \mathrm{ml}$ protein sample was mixed with $5 \mathrm{ml}$ of deionized water. The peristaltic pumps and tangential flow ultrafilter were connected, and the inlet and outlet tubes were subsequently placed in the protein sample to form a loop. The collection tube was placed in a centrifuge tube, and the filtrate was collected without proteins $>30 \mathrm{kDa}$. The filtrate was stored at $-80^{\circ} \mathrm{C}$ and freeze-dried. The dry powder was dissolved in deionized water to a final volume of $250 \mu \mathrm{l}$.

The proteins were next separated with a SPE column. In brief, $250 \mu 1$ samples were mixed with $500 \mu 1$ U9 buffer, followed by incubation at $4^{\circ} \mathrm{C}$ for $30 \mathrm{~min}$ with constant agitation, then $250 \mu \mathrm{l}$ sample buffer was added (2\% TFA and $20 \%$ ACN). Subsequently, 1 tube volume of activation solution $(100 \% \mathrm{ACN})$ was added into the tube. This step was repeated once, then 1 tube volume of equilibration solution ( $0.5 \%$ TFA, $5 \% \mathrm{ACN}$ ) was added (this step was repeated twice). Following this, $1 \mathrm{ml}$ sample was added into the tube and collected, and this step was repeated once more. Subsequently, $2 \mathrm{ml}$ equilibration solution was used to wash the tube, and this step was repeated once. The elution buffer $(250 \mu \mathrm{l})$ at different concentrations (30, 50,70 and $100 \%$ ACN containing $0.1 \%$ TFA) was added, which was repeated once, and the filtrate was collected into a vacuum centrifugal concentrator. Centrifugation was conducted at room temperature for 4-6 h at 10,000 x g. Following centrifugation, $10 \mu$ l mixture was collected.

The target proteins were separated using $12 \%$ Tricine SDS-PAGE (200 $\mu \mathrm{g} /$ lane) and stained with $0.25 \%$ Coomassie Brilliant Blue. The target bands were collected into EP tubes, and $80 \mu \mathrm{l}$ washing buffer $\left(50 \% \mathrm{ACN}\right.$ and $\left.25 \mathrm{mM} \mathrm{NH}_{4} \mathrm{HCO}_{3}\right)$ was subsequently added at $37^{\circ} \mathrm{C}$ for $20 \mathrm{~min}$ with constant agitation. Following three washes and drying at $90^{\circ} \mathrm{C}$ for $15 \mathrm{~min}, 20 \mu \mathrm{l}$ digestion buffer $\left(100 \mathrm{mM} \mathrm{NH}_{4} \mathrm{HCO}_{3}\right)$ and $2 \mu \mathrm{l}$ dilute reductant $\left(100 \mathrm{mM}\right.$ DTT and $100 \mathrm{mM} \mathrm{NH}_{4} \mathrm{HCO}_{3}$ ) were added, followed by incubation at $37^{\circ} \mathrm{C}$ for $10 \mathrm{~min}$. Subsequent to the mixture being allowed to cool to room temperature, $2 \mu \mathrm{l}$ blocker solution (550 mM C ${ }_{2} \mathrm{H}_{4} \mathrm{INO}$ and $100 \mathrm{mM} \mathrm{NH}_{4} \mathrm{HCO}_{3}$ ) was added at room temperature for $10 \mathrm{~min}$, followed by $0.5 \mu \mathrm{l}$ dilute trypsin solution to a final concentration of trypsin at $8 \mathrm{ng} / \mu \mathrm{l}$. Following centrifugation at 3,000 x g for $5 \mathrm{~min}$, the in-gel digestion continued at $37^{\circ} \mathrm{C}$ for $12 \mathrm{~h}$. Centrifugation was performed at $1,000 \mathrm{x} \mathrm{g}$ for $15 \mathrm{~min}$, and the supernatant was harvested.

Following digestion, the peptide mixture was subjected to separation with nano-liquid chromatography (LC), and the resultant mixture was added into a MALDI-TOF-MS. Subsequent to MS/MS, the sequences of corresponding peptides were recognized and searched via Mascot. The corresponding proteins were searched in the Swiss-Prot database (http://www. uniprot.org/). 


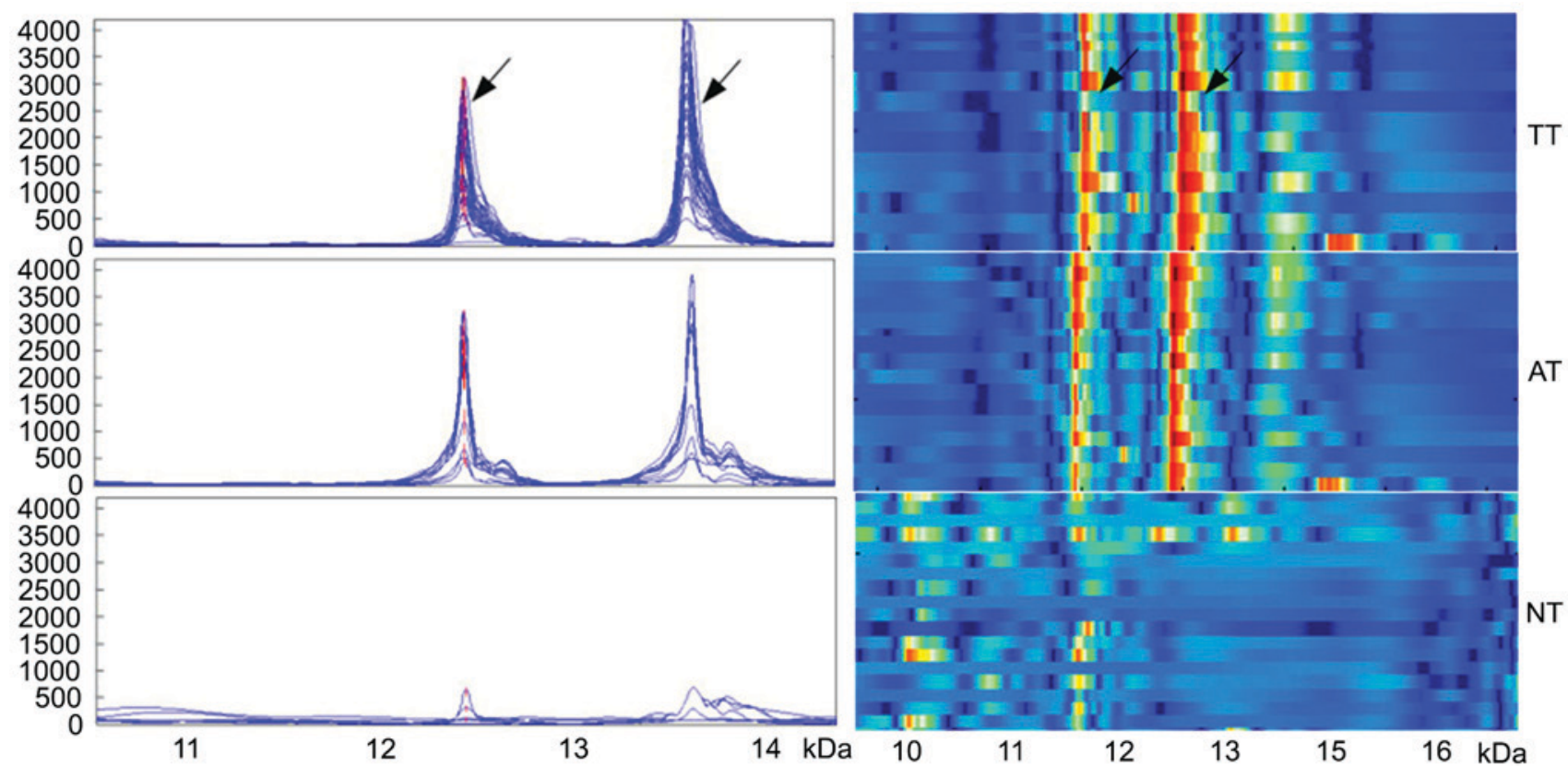

Figure 1. The expression of two proteins in three different tissue types obtained from patients with Wilms' tumor. Arrows denote the proteins at $\mathrm{m} / \mathrm{z} 12138$ and $\mathrm{m} / \mathrm{z} 13462$, identified as macrophage migration inhibitory factor and C-X-C motif ligand 7 chemokine, respectively. The left panel indicates simulated protein peaks, and the right panel of simulated electrophoresis reveals strong to weak expression (red to blue, respectively). TT, tumor tissue; AT, adjacent tissue; NT, normal tissue.

Validation of inflammatory cytokines. Fresh tissues were embedded in paraffin, $5-\mu \mathrm{m}$ sectioned, and deparaffinized with graded ethanol $(100,95,85$ and $75 \%)$. Antigen retrieval was performed in citrate buffer $\left(0.01 \mathrm{M} \mathrm{Na}_{3} \mathrm{C}_{6} \mathrm{H}_{5} \mathrm{O}_{7}-2 \mathrm{H}_{2} \mathrm{O}\right.$, $\mathrm{pH}$ 6.0) for $10 \mathrm{~min}$. Subsequently, sections were treated with $3 \% \mathrm{H}_{2} \mathrm{O}_{2}$ for $30 \mathrm{~min}$ at room temperature to block the endogenous peroxidase and subsequently blocked with goat serum at room temperature for $30 \mathrm{~min}$. Following incubation with the anti-MIF and anti-CXCL7 primary antibodies (1:500 dilution) at $4^{\circ} \mathrm{C}$ for $12 \mathrm{~h}$, the sections were treated with secondary antibodies (1:1,000 dilution) at $37^{\circ} \mathrm{C}$ for $30 \mathrm{~min}$, followed by three washes in PBS. Visualization was conducted with 3,3'-diaminobenzidine for $3 \mathrm{~min}$, which was stopped by washing with flowing water. Counterstaining was performed using hematoxylin. Following dehydration with ethanol and transparentization with xylene, the sections were mounted in neutral gum.

Expression levels of MIF and CXCL7 depended on the mean density of staining. The positive rates of MIF and CXCL7 was determined on the basis of the staining intensity and number of positive cells. Staining intensity: No staining, 0 ; yellow, 1; yellow-brown, 2; and brown, 3. The number of positive cells: $<25 \%, 1 ; \geq 25 \%,<50 \%, 2 ; \geq 50 \%,<75 \%, 3$; and $\geq 75 \%, 4$. The product of the two scores was the final score: -, $0-3 ;+, 3-6 ;++, 6-9$; and,$+++>9$.

Statistical analysis. Quantitative data were compared using two-tailed Student's t-tests with an $\alpha$ of 0.05 between two groups. Kruskal-Wallis tests were employed for comparisons of the quantitative data among groups, followed by paired comparisons with Tamhane's $\mathrm{T}^{2}$ tests $(\alpha=0.05)$. Comparisons of qualitative data among the groups were performed with $\chi^{2}$ tests with an $\alpha$ of 0.05 , and paired comparisons were performed with an $\alpha$ of 0.01 between two groups.

\section{Results}

Screening and identification of inflammatory cytokines. Mass spectrometry data from WT tissues, adjacent normal tissues and normal renal tissues were subjected to standardization with the ZUCI-ProteinChip Data Analysis System, and corresponding protein peaks were obtained using cluster analysis. In WT tissues, five differentially strongly expressed protein peaks were identified, including $\mathrm{m} / \mathrm{z} 12138$ and $\mathrm{m} / \mathrm{z} 13462$ that were identified as being the MIF and the CXCL7 chemokine. The expression of the two inflammation peaks was significantly increased in WT tissues $(1,437.8 \pm 997.3$ and $1,730.4 \pm 1,147.8$, respectively), compared with adjacent normal tissues (952.6 \pm 591.2 and 1,031.1 $\pm 1,120.8$, respectively) and normal renal tissues $(315.4 \pm 296.5$ and $114.7 \pm 118.9$, respectively; all $\mathrm{P}<0.05$; Fig. 1).

Although the expression of the two inflammation peaks was not associated with age or gender $(\mathrm{P}>0.05)$, their expression significantly increased with the progression of WT $(\mathrm{P}<0.001)$ : $678.8 \pm 189.0$ and $746.2 \pm 238.7$, respectively in stage I WT; $664.0 \pm 202.0$ and $1,180.7 \pm 404.9$, respectively in stage II WT; $1,524.7 \pm 407.9$ and $2,160.4 \pm 1,252.3$, respectively in stage III WT; and 2,850.2 \pm 861.2 and 2,498.4 $\pm 1,290.5$, respectively in stage IV WT (Fig. 2). In addition, the expression level of m/z12138 and $\mathrm{m} / \mathrm{z} 13462$ was significantly lower in WT patients with favorable histology compared with those with unfavorable histology $(1,152.3 \pm 735.5$ and $1,281.0 \pm 630.6$, respectively vs. $2,783.9 \pm 872.4$ and 3,848.8 \pm 310.2 , respectively; $\mathrm{P}<0.001$; Fig. 2). Additionally, the expression levels of the two peaks were significantly lower in patients without lymph node metastasis compared with patients with lymph node metastasis $(869.2 \pm 474.6$ and $1,110.2 \pm 433.6$, respectively vs. 2,207.1 \pm 961.7 and $2,569.5 \pm 1,285.2$, respectively; $\mathrm{P}<0.01$; Fig. 3). m/z12138 and m/z13462 expression was also significantly lower in patients without vascular involvement 

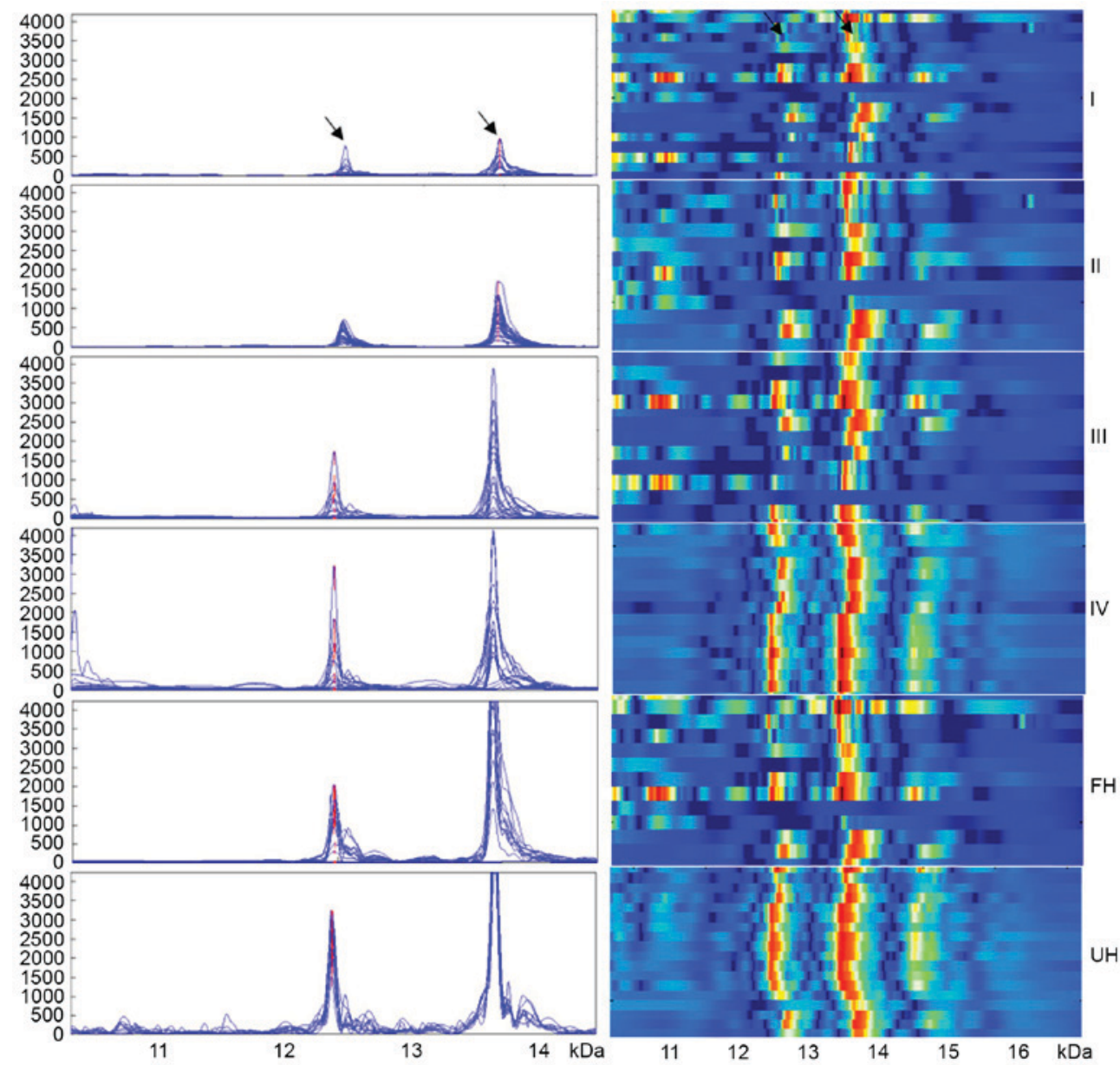

Figure 2. The expression of the two proteins gradually increased with increasing clinical stage of patients with Wilms' tumor. The expression of both proteins was stronger in the $\mathrm{UH}$ group compared with that in the FH group. Arrows denote the proteins at $\mathrm{m} / \mathrm{z} 12138 \mathrm{and} \mathrm{m} / \mathrm{z} 13462$, identified as macrophage migration inhibitory factor and C-X-C motif ligand 7 chemokine, respectively. I, II, III and IV refer to clinical stage. FH, favorable histology; UH, unfavorable histology.
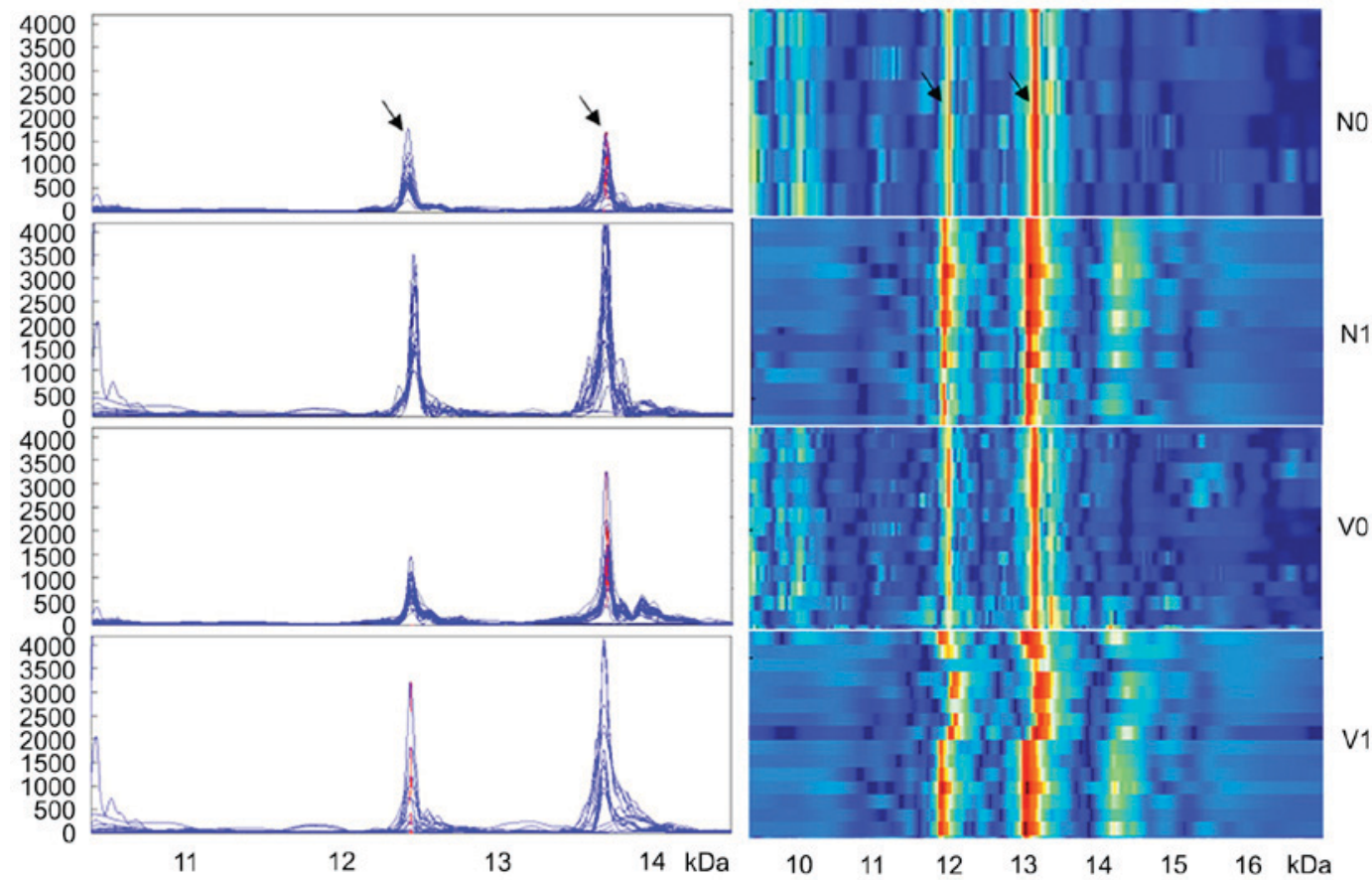

Figure 3. The expression of two proteins were significantly lower in patients with Wilms' tumor without lymph node metastasis compared with patients with lymph node metastasis, and also significantly lower in patients without vascular involvement compared with those with vascular involvement. Arrows denote the proteins at $\mathrm{m} / \mathrm{z} 12138$ and $\mathrm{m} / \mathrm{z} 13462$, identified as macrophage migration inhibitory factor and C-X-C motif ligand 7 chemokine, respectively. N0, no lymph node metastasis; N1, lymph node metastasis; V0, no vascular involvement; V1, vascular involvement. 
Table I. Association between the expression of m/z12138 and m/z13462 peaks and clinical characteristics.

\begin{tabular}{|c|c|c|c|c|c|}
\hline \multirow[b]{2}{*}{ Variables } & \multirow[b]{2}{*}{$\mathrm{n}$} & \multicolumn{2}{|c|}{$\mathrm{m} / \mathrm{z} 12138$} & \multicolumn{2}{|c|}{$\mathrm{m} / \mathrm{z} 13462$} \\
\hline & & Intensity $(\mathrm{x} \pm \mathrm{s})$ & $\mathrm{P}$-value & Intensity $(\mathrm{x} \pm \mathrm{s})$ & P-value \\
\hline Tissue type & & & $<0.001$ & & $<0.001$ \\
\hline TT & 40 & $1,437.8 \pm 997.3$ & $0.031^{\mathrm{a}}$ & $1,730.4 \pm 1,147.8$ & $0.019^{\mathrm{a}}$ \\
\hline AT & 35 & $952.6 \pm 591.2$ & $<0.001^{\mathrm{b}}$ & $1,031.1 \pm 1,120.8$ & $<0.001^{\mathrm{b}}$ \\
\hline NT & 25 & $315.4 \pm 296.5$ & $<0.001^{\mathrm{c}}$ & $114.7 \pm 118.9$ & $<0.001^{\mathrm{c}}$ \\
\hline Gender $^{\mathrm{d}}$ & & & 0.496 & & 0.677 \\
\hline Male & 23 & $1,339.3 \pm 773.0$ & & $1,796.7 \pm 1,063.9$ & \\
\hline Female & 17 & $1,571.1 \pm 1,214.0$ & & $1,640.7 \pm 1,280.6$ & \\
\hline Age, years & & & 0.610 & & 0.655 \\
\hline$<2.5$ & 20 & $1,518.0 \pm 821.2$ & & $1,813.0 \pm 1,310.1$ & \\
\hline$\geq 2.5$ & 20 & $1,357.6 \pm 1,128.1$ & & $1,647.8 \pm 986.6$ & \\
\hline Clinical stage & & & $<0.001$ & & $<0.001$ \\
\hline I & 6 & $678.8 \pm 189.0$ & & $746.2 \pm 238.7$ & \\
\hline II & 12 & $664.0 \pm 202.0$ & & $1,180.7 \pm 404.9$ & \\
\hline III & 13 & $1,524.7 \pm 407.9$ & & $2,160.4 \pm 1,252.3$ & \\
\hline IV & 9 & $2,850.2 \pm 861.2$ & & $2,498.4 \pm 1,290.5$ & \\
\hline Pathological type & & & $<0.001$ & & $<0.001$ \\
\hline $\mathrm{FH}$ & 33 & $1,152.3 \pm 735.5$ & & $1,281.0 \pm 630.6$ & \\
\hline $\mathrm{UH}$ & 7 & $2,783.9 \pm 872.4$ & & $3,848.8 \pm 310.2$ & \\
\hline Lymph node metastasis & & & $<0.001$ & & $<0.001$ \\
\hline $\mathrm{N}$ & 23 & $869.2 \pm 474.6$ & & $1,110.2 \pm 433.6$ & \\
\hline $\mathrm{Y}$ & 17 & $2,207.1 \pm 961.7$ & & $2,569.5 \pm 1,285.2$ & \\
\hline Vascular invasion & & & $<0.001$ & & 0.021 \\
\hline $\mathrm{N}$ & 31 & $1,027.8 \pm 521.3$ & & $1,507.5 \pm 1,019.9$ & \\
\hline $\mathrm{Y}$ & 9 & $2,850.2 \pm 861.2$ & & $2,498.4 \pm 1,290.5$ & \\
\hline
\end{tabular}

${ }^{\mathrm{a} T T}$ vs. AT; ${ }^{\mathrm{b} T T}$ vs. NT; ${ }^{\mathrm{c}} \mathrm{AT}$ vs. NT; ${ }^{\mathrm{d}}$ variables associated with TT. Student's t-test in comparison between two groups. Kruskal-Wallis test in comparison among multiple groups. Tamhane's T2 test in pairwise comparison among multiple groups. Test standard $\alpha=0.05$. TT, tumor tissue; AT, adjacent tissue ( $1 \mathrm{~cm}$ from tumor edge); NT, normal tissue ( $5 \mathrm{~cm}$ from tumor edge); FH, favorable histology; UH, unfavorable histology; $\mathrm{N}$, no; $\mathrm{Y}$, yes.

compared with those with vascular involvement $(1,027.8 \pm 521.3$ and $1,507.5 \pm 1,019.9$, respectively vs. $2,850.2 \pm 861.2$ and $2,498.4 \pm 1,290.5$, respectively; $\mathrm{P} \leq 0.021$; Fig. 3 ). The characteristics of the patients are summarized in Table I.

Upregulated proteins of m/z12138 and m/z13462 in WT were separated and purified by SPE and Tricine-SDS-PAGE, respectively. Following in-gel digestion, the peptide mixture was subjected to LC-MS/MS. Finally, proteins of m/z12138 and m/z13462 were identified as MIF and CXCL7 on the basis of their amino acid sequences through matrix-assisted laser desorption/ionization-TOF-MS (Fig. 4; Table II).

Detection of MIF and CXCL7 by immunohistochemistry. MIF expression was $0.0530 \pm 0.0145$ in WT tissues, $0.0106 \pm 0.0042$ in adjacent normal tissues and $0.0008 \pm 0.0006$ in normal renal tissues $(\mathrm{P}<0.001)$. In addition, CXCL7 expression was $0.0495 \pm 0.0240$ in WT tissues, $0.0138 \pm 0.0063$ in adjacent normal tissues and $0.0009 \pm 0.0005$ in normal renal tissues, $(\mathrm{P}<0.001)$ (Fig. 5; Table III), confirming that the expression levels of the two cytokines were significantly increased in WT.
The number of cells positive for MIF was 92.5\% (37/40) in WT tissues, $57.1 \%(20 / 35)$ in adjacent normal tissues and $16.0 \%(4 / 25)$ in normal renal tissues $(\mathrm{P}<0.01)$. In addition, the number of cells positive for CXCL7 was $87.5 \%$ (35/40) in WT tissues, $48.6 \%(17 / 35)$ in adjacent normal tissues, and $12.0 \%$ $(3 / 25)$ in normal tissues $(\mathrm{P}<0.01$; Table IV).

\section{Discussion}

Proteomics has been employed to investigate the structure, function and characteristics of the proteome in tissues, organs and cells, and has become an important technique in life sciences in the post-genomics era. In our previous studies (2-4), several serum protein markers were identified to be associated with the occurrence and development of breast and thyroid cancer and WT. As the molecular weights of inflammatory cytokines ranges between 10 and $30 \mathrm{kDa}$, the molecular weight was adjusted to a range of 3-30 kDa in the SELDI-TOF-MS. In addition, prior to the separation and purification of the target proteins, proteins $>30 \mathrm{kDa}$ were removed to avoid 
Table II. Identification of the two inflammation protein biomarkers with identified peptides and covered sequence.

\begin{tabular}{lcll}
\hline $\mathrm{m} / \mathrm{z}$ & Protein name & \multicolumn{1}{c}{ Identified peptides } & \multicolumn{1}{c}{ Sequence } \\
\hline 12138 & MIF & PMFIVNTNVPR & MFIVNTNVPRASVPDGFLSELTQQLAQATGKPPQYIA \\
& & RASVPDGFLSELTQQLAQATGK & VHVVPDQLMAFGGSSEPCALCSLHSIGKIGGAQNRSYS \\
& & KSYSKLLCGLLAER & \\
& & LLCGLLAER & GKEESLDSDLYAELRCMCIKTTSGIHPKNIQSLEVIGK \\
13462 & \multirow{2}{*}{ CXCL7 } & GKEESLDSDLYAELR & GTHCNQVEVIATLKDGRKICLDPDAPR \\
& & NIQSLEVIGK & \\
& & GTHCNQVEVIATLK & \\
& & KICLDPDAPR & \\
\hline
\end{tabular}

Bold letters denote the identified peptides that cover the sequence. MIF, macrophage migration inhibitory factor; CXCL7, C-X-C motif ligand 7 chemokine.
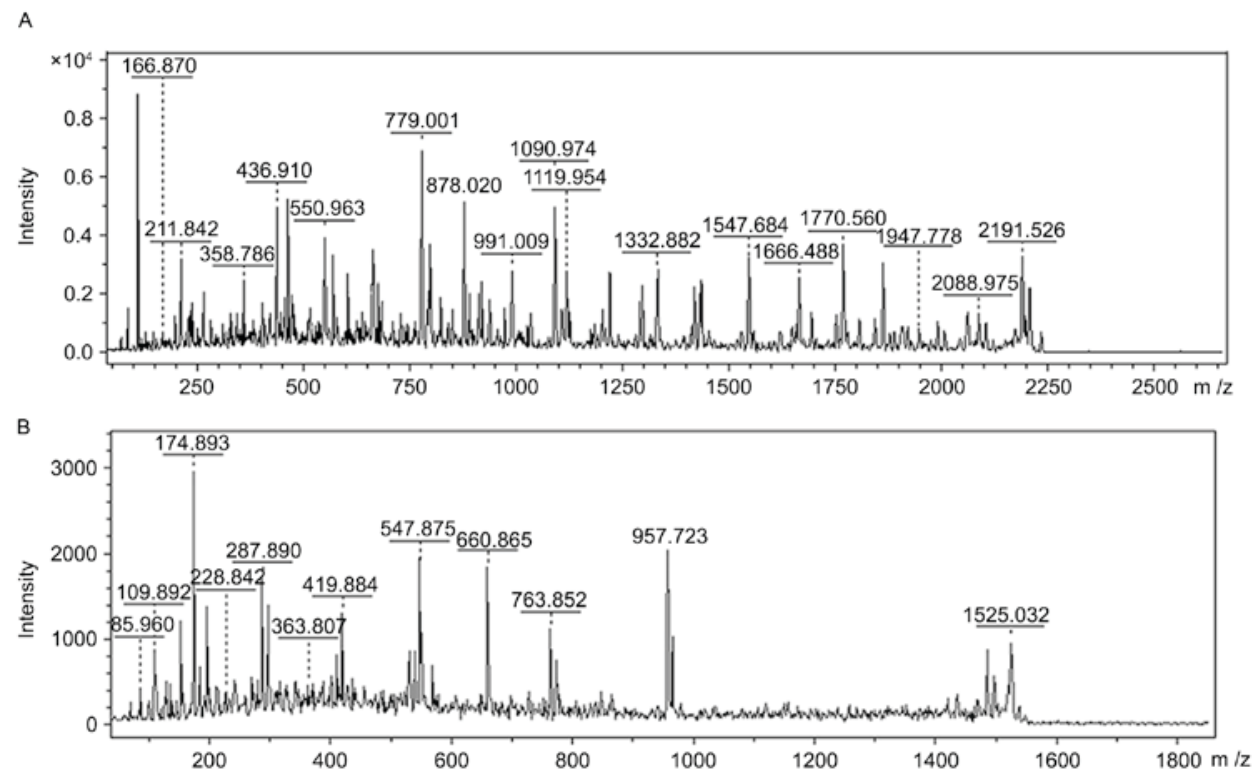

Figure 4. Analysis of peptides obtained subsequent to in-gel digestion. Peptides following digestion were subjected to liquid chromatography- mass spectrometry, and sequences were obtained. (A) $\mathrm{m} / \mathrm{z} 12138$ and (B) $\mathrm{m} / \mathrm{z} 13462$.
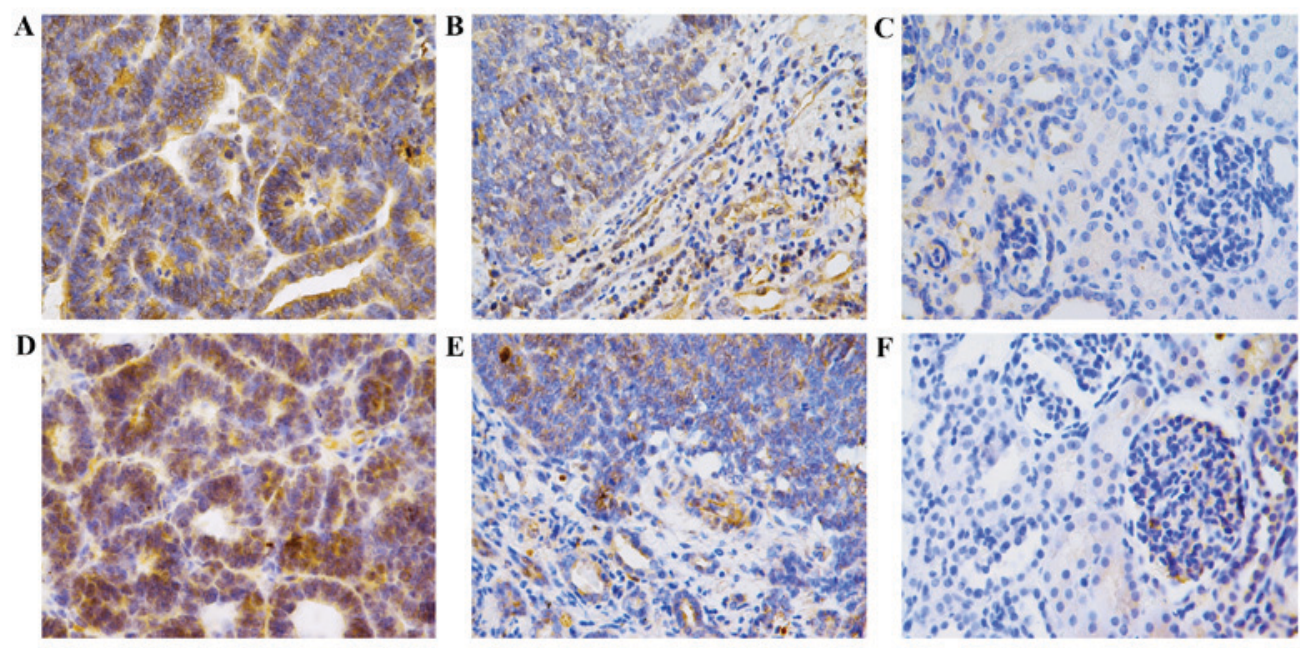

Figure 5. Immunohistochemistry analysis of MIF and CXCL7 expression in WT. All images were taken at magnification, x400 (scale, $50 \mu \mathrm{m}$ ). (A) MIF expression in WT tissue, (B) adjacent normal tissue and (C) normal renal tissue samples. (D) CXCL7 expression in WT tissue, (E) adjacent normal tissue and (F) normal renal tissue samples. MIF, macrophage migration inhibitory factor; CXCL7, C-X-C motif ligand 7 chemokine; WT, Wilm's tumor. 
Table III. Expression of MIF and CXCL7 in TT, AT and NT through immunohistochemistry.

\begin{tabular}{|c|c|c|c|c|c|}
\hline \multirow[b]{2}{*}{ Tissue type } & \multirow[b]{2}{*}{$\mathrm{n}$} & \multicolumn{2}{|c|}{ MIF } & \multicolumn{2}{|c|}{ CXCL7 } \\
\hline & & Mean density & P-value & Mean density & P-value \\
\hline $\mathrm{TT}$ & 40 & $0.0530 \pm 0.0145$ & $<0.001^{\mathrm{a}}$ & $0.0495 \pm 0.0240$ & $<0.001^{\mathrm{a}}$ \\
\hline $\mathrm{AT}$ & 35 & $0.0106 \pm 0.0042$ & $<0.001^{\mathrm{b}}$ & $0.0138 \pm 0.0063$ & $<0.001^{b}$ \\
\hline NT & 25 & $0.0008 \pm 0.0006$ & $<0.001^{\mathrm{c}}$ & $0.0009 \pm 0.0005$ & $<0.001^{\mathrm{c}}$ \\
\hline
\end{tabular}

${ }^{\mathrm{a}} \mathrm{TT}$ vs. AT; ${ }^{\mathrm{T} T T}$ vs. NT; ${ }^{\mathrm{c}} \mathrm{AT}$ vs. NT. MIF, macrophage migration inhibitory factor; CXCL7, C-X-C motif ligand 7 chemokine; TT, tumor tissue; AT, adjacent tissue (1 $\mathrm{cm}$ from tumor edge); NT, normal tissue $(5 \mathrm{~cm}$ from tumor edge).

Table IV. Positive rate of MIF and CXCL7 in TT, AT and NT through immunohistochemistry.

\begin{tabular}{|c|c|c|c|c|c|c|c|}
\hline \multirow[b]{2}{*}{ Tissue type } & \multirow[b]{2}{*}{$\mathrm{n}$} & \multicolumn{2}{|c|}{ MIF } & \multirow[b]{2}{*}{ P-value } & \multicolumn{2}{|c|}{ CXCL7 } & \multirow[b]{2}{*}{ P-value } \\
\hline & & Positive (\%) & Negative (\%) & & Positive (\%) & Negative (\%) & \\
\hline TT & 40 & 37 (92.5) & $3(7.5)$ & $<0.001^{\mathrm{a}}$ & $35(87.5)$ & $5(12.5)$ & $<0.001^{\mathrm{a}}$ \\
\hline AT & 35 & $20(57.1)$ & $15(42.9)$ & $<0.001^{\mathrm{b}}$ & 17 (48.6) & $18(51.4)$ & $<0.001^{\mathrm{b}}$ \\
\hline NT & 25 & $4(16.0)$ & $21(84.0)$ & $0.001^{\mathrm{c}}$ & $3(12.0)$ & $21(88.0)$ & $0.007^{c}$ \\
\hline
\end{tabular}

$\chi^{2}$ test used in comparison among multiple groups, test standard $\alpha=0.05$; pairwise comparison among three groups, test standard $\alpha=0.01$, following Bonferroni method rectification. ${ }^{\mathrm{a} T T}$ vs. AT; ${ }^{\mathrm{b} T T}$ vs. NT; ${ }^{\mathrm{c} A T}$ vs. NT. MIF, macrophage migration inhibitory factor; CXCL7, C-X-C motif ligand 7 chemokine; TT, tumor tissue; AT, adjacent tissue ( $1 \mathrm{~cm}$ from tumor edge); NT, normal tissue ( $5 \mathrm{~cm}$ from tumor edge).

interference in subsequent gel electrophoresis and purification using a tangential flow ultrafilter, which is a reliable biological membrane that may be used to remove proteins $>30 \mathrm{kDa}$. The separation and purification of target proteins is dependent on SPE and gel electrophoresis, so that the subsequent identification may have improved accuracy.

Of the differentially expressed proteins that were upregulated in WT, proteins at m/z12138 and m/z13462 were identified as MIF and CXCL7; their upregulation in WT was confirmed by immunohistochemistry. The expression of these two cytokines was reduced in the adjacent normal tissues and again in the normal tissues compared with the WT tissues, suggesting that the two cytokines are closely associated with the occurrence and development of WT. In addition, their expression increased with the WT progression and increased malignancy. Thus, these cytokines may represent markers indicative of clinical stage and pathological type. Additionally, their expression in tumor samples from patients with WT with lymph node metastasis/vascular involvement was significantly increased compared with adjacent tissue samples, suggesting that each may perform important roles in the invasion and metastasis of WT.

MIF is a multifunctional protein that is primarily synthesized by activated lymphocytes and macrophages (9). It may also be synthesized in the parenchymal cells of the liver, spleen and kidney (10). MIF is an important regulator of inflammation and the immune response, and may also be a key negative regulator that blocks the anti-inflammatory effect of glucocorticoids (10). A previous study has confirmed that MIF may act as a specific biomarker in inflammation-mediated diseases (11). In addition, MIF performs important roles in the proliferation, metastasis, immune escape and angiogenesis of cancer cells, including studies in prostate (12), bladder (13) and lung cancer (14-16), melanoma (17), colon (18), oral (19), breast $(20,21)$ and head and neck squamous cell cancer (22). In glioma (23), ovarian cancer (24) and neuroblastoma (25), MIF may inhibit the cytotoxicity of NK cells and T-lymphocytes, facilitating the immune escape of cancer cells and compromising the clearance of cancer cells by the immune system. Thus, MIF may represent a biomarker for the diagnosis of malignancies, and a novel therapeutic target that may improve the killing of cancer cells by the immune system.

CXCL7, a member of the CXC chemokine subfamily, is involved in inflammation. CXCL7 as a chemical irritant may induce the directional migration of leukocytes, and is primarily secreted by macrophages, lymphocytes, endothelial cells and fibroblasts. CXCL7, as an important cytokine, is not only involved in a variety of physiological and pathological processes including hemopoiesis and inflammation reaction (26-30), but is also closely associated with the occurrence and development of numerous types of cancer (31-35). However, to the best of our knowledge, the roles of MIF and CXCL7 in WT have not previously been examined.

Pathological examination is the most commonly used method for the diagnosis of WT. However, there is no widely accepted pathological marker indicative of cancer progression. The results of the present study demonstrated that MIF and CXCL7 may become important biomarkers indicative of clinical stage and pathological type of WT. Chemotherapy and immune therapy are the main strategies used for patients with WT. The wide application of an MIF blocker (36) provides a 
novel prospect for the therapy of WT. However, the specific biological roles of MIF and CXCL7 in WT remain poorly understood, and additional studies are required to confirm them.

\section{References}

1. Metzger ML and Dome JS: Current therapy for Wilms' tumor Oncologist 10: 815-826, 2005.

2. Fan Y, Shi L, Liu Q, Dong R, Zhang Q, Yang S, Fan Y, Yang H, Wu P, Yu J, et al: Discovery and identification of potential biomarkers of papillary thyroid carcinoma. Molecular Cancer 8 : 79, 2009.

3. Zhang Q, Wang J, Dong R, Yang S and Zheng S: Identification of novel serum biomarkers in child nephroblastoma using proteomics technology. Mol Biol Rep 38: 631-638, 2011.

4. Fan Y, Wang J, Yang Y, Liu Q, Fan Y, Yu J, Zheng S, Li M and Wang J: Detection and identification of potential biomarkers of breast cancer. J Cancer Res Clin 136: 1243-1254, 2010.

5. Mitchell JK, Lemon SM and McGivern DR: How do persistent infections with hepatitis $\mathrm{C}$ virus cause liver cancer? Curr Opin Virol 14: 101-108, 2015.

6. Umansky V and Sevko A: Overcoming immunosuppression in the melanoma microenvironment induced by chronic inflammation. Cancer Immunol Immunother 61: 275-282, 2012.

7. Kanterman J, Sade-Feldman M and Baniyash M: New insights into chronic inflammation-induced immunosuppression. Semin Cancer Biol 22: 307-318, 2012.

8. Ringelhan M, O'Connor T, Protzer U and Heikenwalder M: The direct and indirect roles of HBV in liver cancer: Prospective markers for HCC screening and potential therapeutic targets J Pathol 235: 355-367, 2015.

9. Lue H, Kleemann R, Calandra T, Roger T and Bernhagen J: Macrophage migration inhibitory factor (MIF): Mechanisms of action and role in disease. Microbes Infect 4: 449-460, 2002

10. Calandra $\mathrm{T}$ and Roger T: Macrophage migration inhibitory factor: A regulator of innate immunity. Nat Rev Immunol 3: 791-800, 2003

11. Grieb G, Merk M, Bernhagen J and Bucala R: Macrophage migration inhibitory factor (MIF): A promising biomarker. Drug News Perspect 23: 257-264, 2010.

12. Meyer-Siegler KL, Iczkowski KA, Leng L, Bucala R and Vera PL: Inhibition of macrophage migration inhibitory factor or its receptor (CD74) attenuates growth and invasion of DU-145 prostate cancer cells. J Immunol 177: 8730-8739, 2006.

13. Choudhary S, Hegde P, Pruitt JR, Sielecki TM, Choudhary D, Scarpato K, Degraff DJ, Pilbeam CC and Taylor JA III: Macrophage migratory inhibitory factor promotes bladder cancer progression via increasing proliferation and angiogenesis. Carcinogenesis 34: 2891-2899, 2013.

14. Arenberg D, Luckhardt TR, Carskadon S, Zhao L, Amin MA and Koch AE: Macrophage migration inhibitory factor promotes tumor growth in the context of lung injury and repair. Am J Resp Crit Care 182: 1030-1037, 2010.

15. Gámez-Pozo A, Sánchez-Navarro I, Calvo E, Agulló-Ortuño MT, López-Vacas R, Díaz E, Camafeita E, Nistal M, Madero R, Espinosa $\mathrm{E}$, et al: PTRF/Cavin-1 and MIF proteins are identified as non-small cell lung cancer biomarkers by label-free proteomics. PLoS One 7: e33752, 2012.

16. McClelland M, Zhao L, Carskadon S and Arenberg D: Expression of $\mathrm{CD} 74$, the receptor for macrophage migration inhibitory factor, in non-small cell lung cancer. Am J Pathol 174: 638-646, 2009.

17. Tanese K, Hashimoto Y, Berkova Z, Wang Y, Samaniego F, Lee JE, Ekmekcioglu S and Grimm EA: Cell Surface CD74-MIF interactions drive melanoma survival in response to interferon- $\gamma$. J Invest Dermatol 135: 2775-2784, 2015.

18. Gordon-Weeks AN, Lim SY, Yuzhalin AE, Jones K and Muschel R: Macrophage migration inhibitory factor: A key cytokine and therapeutic target in colon cancer. Cytokine Growth Factor Rev 26: 451-461, 2015.

19. Chang KP, Lin SJ, Liu SC, Yi JS, Chien KY, Chi LM, Kao HK, Liang Y, Lin YT, Chang YS and Yu JS: Low-molecular-mass secretome profiling identifies HMGA2 and MIF as prognostic biomarkers for oral cavity squamous cell carcinoma. Sci Rep 5: $11689,2015$.
20. Verjans E, Noetzel E, Bektas N, Schütz AK, Lue H, Lennartz B, Hartmann A, Dahl E and Bernhagen J: Dual role of macrophage migration inhibitory factor (MIF) in human breast cancer. BMC Cancer 9: 230, 2009

21. Richard V, Kindt NG, Decaestecker C, Gabius HJ, Laurent G, Noël JC and Saussez S: Involvement of macrophage migration inhibitory factor and its receptor (CD74) in human breast cancer. Oncol Rep 32: 523-529, 2014

22. Kindt N, Lechien JR, Nonclercq D, Laurent G and Saussez S: Involvement of CD74 in head and neck squamous cell carcinomas. J Cancer Res Clin 140: 937-947, 2014.

23. Mittelbronn M, Platten M, Zeiner P, Dombrowski Y, Frank B, Zachskorn C, Harter PN, Weller M and Wischhusen J: Macrophage migration inhibitory factor (MIF) expression in human malignant gliomas contributes to immune escape and tumour progression. Acta Neuropathol 122: 353-365, 2011

24. Krockenberger M, Dombrowski Y, Weidler C, Ossadnik M, Hönig A, Häusler S, Voigt H, Becker JC, Leng L, Steinle A, et al: Macrophage migration inhibitory factor (MIF) contributes to the immune escape of ovarian cancer by downregulating NKG2D1. J Immunol 180: 7338-7348, 2008.

25. Zhou Q, Yan X, Gershan J, Orentas RJ and Johnson BD: Expression of macrophage migration inhibitory factor by neuroblastoma leads to the inhibition of antitumor T cell reactivity in vivo. J Immunol 181: 1877-1886, 2008.

26. Pillai MM, Iwata M, Awaya N, Graf L and Torok-Storb B: Monocyte-derived CXCL7 peptides in the marrow microenvironment. Blood 107: 3520-3526, 2006.

27. Pecks U, Kirschner I, Wölter M, Schlembach D, Koy C, Rath W and Glocker MO: Mass spectrometric profiling of cord blood serum proteomes to distinguish infants with intrauterine growth restriction from those who are small for gestational age and from control individuals. Transl Res 164: 57-69, 2014.

28. Ehlken C, Grundel B, Michels D, Junker B, Stahl A, Schlunck G, Hansen LL, Feltgen N, Martin G, Agostini HT and Pielen A: Increased expression of angiogenic and inflammatory proteins in the vitreous of patients with ischemic central retinal vein occlusion. PLoS One 10: e0126859, 2015.

29. Yeo L, Adlard N, Biehl M, Juarez M, Smallie T, Snow M, Buckley CD, Raza K, Filer A and Scheel-Toellner D: Expression of chemokines CXCL4 and CXCL7 by synovial macrophages defines an early stage of rheumatoid arthritis. Ann Rheum Dis 75: 763-771, 2016.

30. Ghasemzadeh M, Kaplan ZS, Alwis I, Schoenwaelder SM, Ashworth KJ, Westein E, Hosseini E, Salem HH, Slattery R, McColl SR, et al: The CXCR1/2 ligand NAP-2 promotes directed intravascular leukocyte migration through platelet thrombi. Blood 121: 4555-4566, 2013.

31. Giuliano S, Guyot M, Grépin R and Pagès G: The ELR ${ }^{+} \mathrm{CXCL}$ chemokines and their receptors CXCR1/CXCR2: A signaling axis and new target for the treatment of renal cell carcinoma. OncoImmunology 3: e28399, 2014.

32. Matsubara J, Honda K, Ono M, Tanaka Y, Kobayashi M, Jung G, Yanagisawa K, Sakuma T, Nakamori S, Sata N, et al: Reduced plasma level of $\mathrm{CXC}$ chemokine ligand 7 in patients with pancreatic cancer. Cancer Epidemiol Biomarkers Prev 20: 160-171, 2011.

33. Tang Z, Yu M, Miller F, Berk RS, Tromp G and Kosir MA: Increased invasion through basement membrane by CXCL7-transfected breast cells. Am J Surg 196: 690-696, 2008.

34. Grépin R, Guyot M, Giuliano S, Boncompagni M, Ambrosetti D, Chamorey E, Scoazec JY, Negrier S, Simonnet H and Pagès G: The CXCL7/CXCR1/2 axis is a key driver in the growth of clear cell renal cell carcinoma. Cancer Res 74: 873-883, 2014.

35. Desurmont T, Skrypek N, Duhamel A, Jonckheere N, Millet G, Leteurtre E, Gosset P, Duchene B, Ramdane N, Hebbar M, et al: Overexpression of chemokine receptor CXCR2 and ligand CXCL7 in liver metastases from colon cancer is correlated to shorter disease-free and overall survival. Cancer Sci 106: 262-269, 2015.

36. Xu L, Li Y, Sun H, Zhen X, Qiao C, Tian S and Hou T: Current developments of macrophage migration inhibitory factor (MIF) inhibitors. Drug Discov Today 18: 592-600, 2013. 